\title{
Bahan Ajar E-Modul Menggunakan Aplikasi Sigil Pada Materi Transformasi Geometri
}

\author{
Zuzilawati ${ }^{1}$, Rindang Kembar Sari ${ }^{2}$, Haida Fitri ${ }^{3 *}$ \\ 1,2,3Institut Agama Islam Negeri (IAIN) Bukittinggi, Bukittinggi, Indonesia \\ ${ }^{*}$ Corresponding Author
}

\begin{tabular}{|c|}
\hline Informasi Artikel \\
\hline $\begin{array}{l}\text { Diterima Redaksi: } 10 \text { Februari } 2021 \\
\text { Revisi Akhir: } 21 \text { Maret } 2021 \\
\text { Diterbitkan Online: } 30 \text { Juni } 2021\end{array}$ \\
\hline Kata Kunci \\
\hline $\begin{array}{l}\text { e-modul } \\
\text { Aplikasi Sigil } \\
\text { Transformasi Geometri }\end{array}$ \\
\hline Korespondensi \\
\hline
\end{tabular}

\section{A B S T R A C T}

\begin{abstract}
The purpose of this research is to develop e-module teaching materials using the sigil application. The type of this research is research and development (ReD). The development model used is a combination of 3-D and Luther Sutopo models, namely define, design, develop (concept, desing, collecting, assembly, testing and distribution materials). After the product was produced based on the results of product trials for aspects of validity, material experts and media experts obtained $82 \%$ which is very valid. Aspects of practicality for teachers and students with a percentage of $78.34 \%$ or practical, and for the effectiveness test the effective criteria are $77 \%$ while the test results are $82.56 \%$ with very effective criteria. So it can be concluded that the design of e-module teaching materials using the sigil application on the subject of Geometric Transformation for class XI SMA students is valid, practical and effective.

Tujuan penelitian ini untuk mengembangkan bahan ajar e-modul menggunakan aplikasi sigil. Adapun jenis penelitian ini adalah penelitian dan pengembangan (Research and Development/ $R \ll D)$. Model pengembangan yang digunakan adalah mengkombinasikan antara 3-D dan model Luther Sutopo yaitu define, design, develop (concept, desing, material collecting, assembly, testing dan distribution). Setelah produk dihasilkan berdasarkan hasil uji coba produk untuk aspek kevalidan pada ahli materi dan ahli media memperoleh $82 \%$ yaitu sangat valid. Aspek kepraktisan bagi guru dan siswa dengan persentase $78,34 \%$ atau praktis, dan untuk uji efektifitas memperoleh kriteria efektif sebesar $77 \%$ sedangkan dari hasil tes diperoleh $82,56 \%$ dengan kriteria sangat efektif. Jadi dapat disimpulkan bahwa rancangan bahan ajar e-modul menggunakan aplikasi sigil pada pokok bahasan Transformasi Geometri untuk anak kelas XI SMA dinyatakan valid, praktis dan efektif .
\end{abstract}

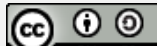

02021 by the authors. Submitted for possible open access publication under the terms and conditions of the Crea tive Commons Attribution-ShareAlike 4.0 International License-(CC-BY-SA) (https://creativecommons.org/licenses/by-sa/4.0/)

\section{Pendahuluan}

Dewasa ini dunia pendidikan telah memasuki revolusinya yang kelima. Pertama, terjadi ketika orang menyerahkan pendidikan anaknya kepada seorang guru. Kedua, ketika digunakannya tulisan untuk keperluan pembelajaran. Ketiga, ketika ditemukannya mesin cetak sehingga materi pembelajaran dapat disajikan melalui media cetak. Keempat, ketika digunakannya perangkat elektronik seperti radio dan televisi untuk pemerataan dan perluasan pendidikan. Kelima, seperti saat ini, dengan dimanfaatkannya teknologi informasi dan komunikasi tercanggih, khususnya komputer dan internet untuk digunakan dalam kegiatan pendidikan.[1]

Agar proses belajar mengajar berjalan dengan lancar maka diperlukan suatu sumber belajar yang sesuai dengan karakter siswa, mata pelajaran yang disampaikan, suasana dan prasarana penunjang serta tentunya sesuai dengan perkembangan zaman. Sumber belajar dapat diperoleh dimana saja. Ditinjau dari tipe atau asal usulnya, sumber belajar dapat dibedakan menjadi dua jenis, yaitu: pertama sumber belajar yang dirancang (learning resources by design) yaitu sumber belajar yang secara khusus atau sengaja dirancang atau dikembangkan untuk mencapai tujuan pembelajaran tertentu. Contohnya, buku pelajaran, modul, program VCD pembelajaran, program audio pembelajaran. Kedua sumber belajar yang sudah tersedia dan tinggal dimanfaatkan (learning resources by utilization), yaitu sumber belajar yang secara tidak khusus dirancang atau dikembangkan untuk keperluan pembelajaran, tetapi dapat dipilih dan 
dimanfaatkan untuk keperluan pembelajaran. Contohnya surat kabar, siaran televisi pasar, sawah, museum, pemerintahan, tenaga ahli, pemuka agama, olahragawan, dan lain-lain.[2]

PP tahun 2005 pasal 20, bahwa guru diharapkan mengembangkan materi pembelajaran, yang kemudian dipertegas melalui Peraturan Menteri Pendidikan Nasional (Permendiknas) nomor 41 tahun 2007 tentang Standar Proses, yang antara lain mengatur tentang perencanaan proses pembelajaran yang mensyaratkan bagi guru pada satuan pendidikan untuk mengembangkan rencana pelaksanaan pembelajaran (RPP). Salah satu elemen dalam RPP adalah sumber belajar. dengan demikian, guru diharapkan untuk mengembangkan bahan ajar sebagai salah satu sumber belajar. [3]

Bahan ajar adalah segala bentuk bahan yang digunakan untuk membantu guru/instruktur dalam melaksanakan kegiatan belajar mengajar di kelas. Bahan yang dimaksud bisa berupa bahan tertulis maupun bahan tidak tertulis. Bahan ajar merupakan informasi, alat dan teks yang diperlukan guru/instruktur untuk perencanaan dan penelaahan implementasi pembelajaran[4]. Menurut Prastowo, bahan ajar dikelompokkan berdasarkan bentuk dan cara kerjanya. Bahan ajar menurut bentuknya dapat berupa bahan ajar cetak, bahan ajar dengar, dan bahan ajar pandang dengar. Sedangkan bahan ajar menurut cara kerjanya terdiri atas bahan ajar yang tidak diproyeksikan, bahan ajar yang diproyeksikan, bahan ajar audio, bahan ajar video, dan bahan ajar media komputer[5].

Pada saat sekarang dengan adanya perkembangan teknologi yang sangat pesat, bahan ajar yang tersedia tidak hanya berupa buku saja, tetapi sudah banyak bahan ajar yang diproduksi dengan bahan bakunya diperoleh dari internet. Contohnya buku elektronik (e-book), modul elektronik (e-modul) sehingga memudahkan siswa untuk mengakses berbagai materi yang akan dipelajari. Salah satu implementasi kurikulum 2013 yang dirancang oleh Depertemen jenderal pendidikan dasar dan menengah yaitu modul elektronik (e-modul). Menurut Dede, e-modul adalah bahan belajar yang dirancang secara sistematis berdasarkan kurikulum tertentu dan dikemas dalam bentuk satuan waktu tertentu, yang ditampilkan menggunakan piranti elektronik misalnya komputer atau android.[6] E-modul merupakan inovasi baru dalam penyajian sebuah modul, dimana menggunakan perangkat komputer atau android. Perbedaan antara modul dan e-modul terlihat pada format penyajian secara fisik. Pada umumnya e-modul mengadaptasi komponen-komponen yang terdapat pada modul cetak yang dapat dilihat pada Tabel 1. [7]

Tabel 1. Perbandingan Antara E-Modul dengan Modul Cetak

\begin{tabular}{ll}
\hline \multicolumn{1}{c}{ E-modul } & \multicolumn{1}{c}{ Modul Cetak } \\
\hline $\begin{array}{l}\text { Format elektronik (dapat } \\
\text { berupa file, doc,. Exe,. Swf, dll) }\end{array}$ & $\begin{array}{l}\text { Format berbentuk cetak } \\
\text { (kertas) }\end{array}$ \\
\hline $\begin{array}{l}\text { Ditampilkan menggunakan } \\
\text { perangkat elektronik dan } \\
\text { software khusus (laptop, PC, } \\
\text { HP, internet) }\end{array}$ & $\begin{array}{l}\text { Tampilannya berupa } \\
\text { kumpulan kertas yang } \\
\text { tercetak }\end{array}$ \\
\hline Lebih praktis untuk di bawa & $\begin{array}{l}\text { Berbentuk fisik, untuk } \\
\text { membawa dibutuhkan ruang } \\
\text { untuk meletakkan }\end{array}$ \\
\hline Biaya produksi lebih murah & Biaya produksi lebih mahal \\
\hline $\begin{array}{l}\text { Tahan lama dan tidak akan } \\
\text { lapuk dimakan waktu }\end{array}$ & $\begin{array}{l}\text { Daya tahan kertas terbatas } \\
\text { oleh waktu }\end{array}$ \\
\hline Menggunakan sumber daya & $\begin{array}{l}\text { Tidak perlu sumber daya } \\
\text { khusus untuk } \\
\text { tenaga listrik }\end{array}$ \\
\hline $\begin{array}{l}\text { Dapat dilengkapi dengan audio } \\
\text { atau video dalam penyajiannya }\end{array}$ & $\begin{array}{l}\text { Tidak dapat dilengkapi } \\
\text { dengan audio atau video } \\
\text { dalam penyajiannya }\end{array}$ \\
\hline
\end{tabular}


Beberapa aplikasi yang dapat digunakan dalam pembuatan e-modul yaitu adobe flash, kvisoft flipbook maker, dan sigil. Aplikasi sigil memiliki banyak kelebihan diantaranya[8]: (a) Aplikasi pembuat buku digital freeware dengan fitur terlengkap dari pada pembuatan buku digital lain saat ini. (b) Running Test dan hasil prototipe ringan dan mudah dioperasikan. (c) Friendly pada semua jenis perangkat pembaca dan fleksibel dalam pemakaian, pembaca dapat memutar video dengan menghidupkan sendiri oleh pengguna, bukan berjalan sendiri seperti aplikasi buku digital lain yang otomatis berjalan sendiri. (d) Semakin mudah dan lengkap isi bacaan semakin tinggi minat baca pembaca dalam memperdalam ilmu pengetahuannya.

Berdasarkan kelebihan dari aplikasi Sigil di atas dan hasil wawancara dengan guru matematika di SMAN 1 Ampek Angkek serta obeservasi yang peneliti lakukan dimana sarana prasarana sangat mendukung dari segi teknologi dan SMAN 1 Ampek Angkek menggiatkan pembelajaran berbasis IT maka dalam penelitian ini untuk membuat e-modul aplikasi yang digunakan adalah aplikasi Sigil.

Sigil adalah sebuah perangkat lunak editor untuk epub yang bersifat open source (sumber terbuka)[9]. Sigil mendukung format text, $h t m l$, dan format epub. Dengan kecanggihan teknologi telah merubah kebiasaan orang untuk membaca. Membaca buku bisa dilakukan secara digital dalam bentuk book digital electronic publication (epub). Cukup banyak penelitian sebelumnya yang mengembangkan bahan ajar e-modul dengan menggunakan aplikasi Sigil ini seperti pengembangan e-modul yang dilakukan oleh Fitria Reza Amalia dan Rudy Kustijono, dilakukan pada mata pelajaran fisika dan untuk melatih kemampuan berfikir kritis siswa [8]. Penelitian yang dilakukan oleh Intan Sari dengan mengembangkan e-modul dengan aplikasi Sigil pada mata pelajaran TIK [10], sedangkan penelitian yang dilakukan Pangestuning Maharani dkk yang memaparkan keunggulan dari aplikasi Sigil [11]. Perbedaan dengan penelitian ini, pengembangan e-modul dengan aplikasi Sigil dilakukan pada mata pelajaran matematika dengan materi Transformasi Geometri.

\section{Metode Penelitian}

\subsection{Jenis, Waktu dan Tempat Penelitian}

Penelitian ini merupakan jenis penelitian pengembangan (Research and Development $/ R \& D$ ). Penelitian ini menggunakan pengembangan prosedural menurut pandangan S.Thagarajan, Dorothy S. Semmel, dan Melvyn I. Semmel yaitu Define, Design, Develop, dan Desseminate atau yang dikenal dengan model 4-D. Namun, penelitian hanya dilakukan pada tahapan Define (pendefinisian), Design (perancangan), dan Develop (pengembangan). Untuk mengembangkan media, penelitian menggunakan multimedia versi Luther Sutopo dengan enam tahapan yaitu concept (pengonsepan), design (perancangan), material colecting (pengumpulan materi), assembly (pembuatan), testing (pengujian), dan tahap distribution (pendistribusian).[12] Model prosedural yaitu model deskriptif yang menggambarkan alur atau langkah-langkah prosedural yang harus diikuti untuk menghasilkan suatu produk tertentu. [13]. Pada Gambar 1 diperlihatkan secara singkat diagram alir tahapan pengembangan e-modul. 


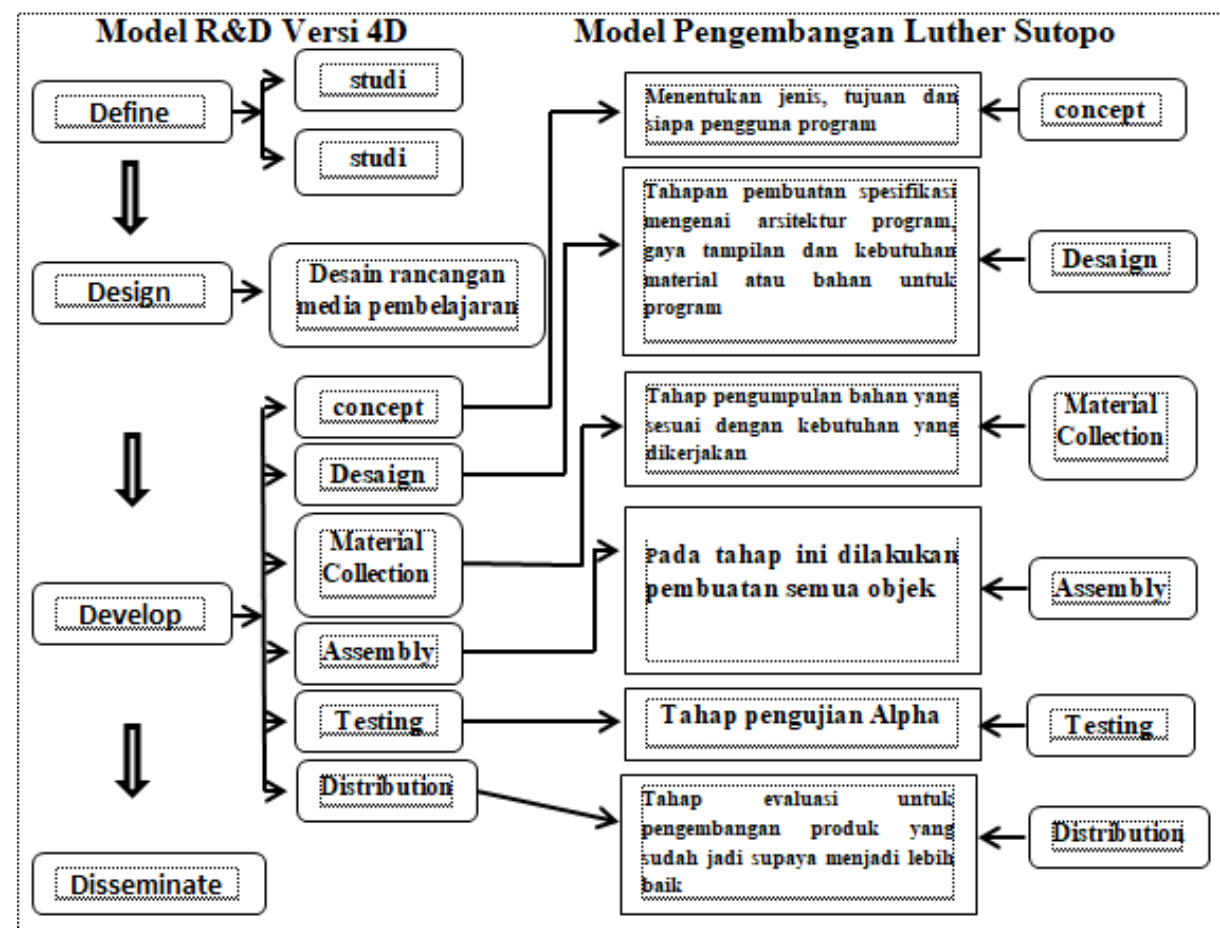

Gambar 1. Skema Metode R\&D Versi 4D dengan Model Pengembangan Luther Sutopo

Untuk lebih jelasnya berikut ini aka diuraikan setiap langkah-langkah metode R\&D versi 4D dengan model pengembangan Luther Sutopo ,yaitu:

\section{Define (Tahap Pendefinisian)}

Menurut Trianto [14] terdapat 5 langkah pokok, yaitu: (a) Analisis ujung depan yang bertujuan untuk memunculkan masalah dasar yang dihadapi dalam pembelajaran. (b) Analisis siswa bertujuan mentelaah karakteristik siswa sesuai dengan desain pengembangan perangkat pembelajaran. (c) Analisis tugas dilakukan untuk merinci isi materi ajar dalam bentuk garis besar berupa analisis struktur isi dan analisis indikator. (d) Analisis konsep bertujuan untuk mengidentifikasi konsep-konsep utama yang akan diajarkan. (e) Perumusan tujuan pembelajaran atau indikator pencapaian hasil belajar berdasarkan pada Kompetensi Dasar (KD) dan indikator yang tercantum dalam kurikulum tentang konsep suatu materi.

\section{Design (Tahap Perencanaan)}

Tahap design di antaranya (a) Mengumpulkan referensi materi. (b) Menyusun kerangka bahan ajar e-modul. (c) Merancang pembelajaran sesuai tujuan pembuatan bahan ajar e-modul. (d) Menyusun materi sesuai kerangka dan alur pembelajaran yang dirancanakan untuk bahan ajar e-modul. (e) Melengkapi unsur-unsur bahan ajar e-modul sesuai kerangka. (f) Merancang tampilan atau layout bahan ajar e-modul Matematika.

\section{Develop (Tahap Pengembangan)}

Pada tahapan inilah tahapan pengembangan multimedia versi Luther Sutopo yang telah dimodifikasi dilaksanakan, menurut Iwan [12] dengan tahapan sebagai berikut. (a) Concept (konsep) yaitu menentukan tujuan, termasuk identifikasi audiens, macam aplikasi (presentasi, interaktif, dan lain-lain), tujuan aplikasi (informasi, hiburan, pelatih, dan lain-lain dan spesifikasi umum). (b) Design (perancangan) yaitu tahap pembuatan spesifikasi mengenai arsitektur program, gaya, tampilan, dan kebutuhan material atau bahan untuk program. Pada tahapan ini juga merancang struktur navigasi, storyboard, dan user interface. (c) Material Collecting yaitu 
tahap pengumpulan bahan yang sesuai dengan kebutuhan yang dikerjakan. (d) Assembly yaitu tahap pembuatan semua objek atau bahan multimedia. (e) Testing (pengujian) dilakukan setelah menyelesaikan tahap pembuatan (assembly) dengan menjalankan aplikasi program dan melihatnya apakah ada kesalahan atau tidak. Tahap ini disebut juga tahap pengujian alpha (alpha test) yang pengujiannya dilakukan oleh pembuat atau lingkungan pembuat sendiri. Emodul yang dihasilkan akan dilakukan beberapa pengujian kepada para pakar, yang bertujuan untuk menghasilkan produk yang sudah direvisi, berdasarkan masukan dari pakar.

Tahap ini dilakukan dengan langkah sebagai berikut. (a) Uji Validitas E-modul. Menurut Hafiz [15] aspek pertama penentuan kualitas produk pembelajaran adalah validitas (kesahihan). Pada tahap ini dilakukan penilaian terhadap produk yang akan dibuat. Penilaian dilakukan oleh beberapa validator yang terdiri dari 2 dosen dari jurusan matematika sebagai ahli materi, 2 dosen diluar jurusan matematika sebagai ahli media, 2 orang guru matematika dan 1 guru sebagai ahli bahasa. (b) Uji Praktikalitas E-modul. Aspek kedua penentuan kualitas produk pembelajaran adalah kepraktisan. Menurut Nieveen dalam Hafiz [15] dalam penelitiannya menyatakan bahwa tingkat kepraktisan dilihat dari penjelasan apakah guru dan pakar-pakar lainnya memberikan pertimbangan bahwa materi mudah dan dapat digunakan oleh guru dan siswa. Pada tahapan ini peneliti melakukan uji coba tebatas pada 32 orang siswa kelas XI dan 1 orang guru sebagai pengguna bahan ajar e-modul dengan kriteria kemudahan penggunaan, daya tarik, dan efesiensi. (c) Uji Efektifitas E-modul. Keefektifan produk dapat ditentukan dari hasil pengamatan keterampilan, respons, dan hasil belajar.[15] Pada tahap ini dilakukan pemberian angket uji efektifitas untuk mengetahui respons apa yang diperoleh dari siswa yang berjumlah 32 orang dan tes untuk mengetahui hasil belajar siswa terhadap materi transformasi geometri dengan menggunakan e-modul. (d) Disribution merupakan proses penyimpanan. Jika media penyimpanan tidak cukup untuk menampung aplikasinya, maka dilakukan kompresi terhadap aplikasi tersebut. Tahapan distribution (distribusi) juga tidak akan dilakukan karena keterbatasan waktu dan biaya penelitian yang dimiliki oleh peneliti. (e) Disseminate (tahap penyebaran).

Menurut Trianto [14] dissemate merupakan tahapan penggunaan perangkat yang telah dikembangkan pada skala yang lebih luas, misalnya di kelas lain, di sekolah lain, dan oleh guru lain. Namun, karena keterbatasan waktu dan biaya penelitian pada tahapan ini tidak dilakukan. Penelitian dilakukan pada kelas XI MIPA 1 SMAN 1 Ampek Angkek. Pemilihan tempat penelitian didasari atas pertimbangan bahwa kondisi dan sarana yang ada pada sekolah sudah memadai sehingga sudah dapat mendukung dilaksananya penelitian. Subjek penelitian dilakukan kepada 32 orang siswa dengan membuatkan sebuah bahan ajar e-modul menggunakan aplikasi sigil dengan materi transformasi geometri.

\subsection{Instrumen Pengumpulan Data}

Menurut Sugiono [16] instrumen penelitian adalah suatu alat yang digunakan untuk mengukur fenomena alam maupun sosial yang diamati. Instrumen yang dipergunakan untuk mengumpulkan data pada penelitian ini adalah: (a) Lembar Validasi. Lembar validasi dipergunakan untuk memperoleh data tentang validitas e-modul yang dikembangkan valid atau tidak. Lembar validasi ini diberikan pada validator. Pelaksanaan ini juga memberikan masukanmasukan untuk memperbaiki bahan ajar sehingga layak untuk digunakan pada tahap testing (pengujian). Lembar validasi ini akan diberikan kepada 2 ahli yaitu lembar validasi untuk ahli materi dan pelajaran meliputi aspek tujuan, rasional, isi modul, karakteristik, kesesuaian dengan bahasa, dan kemasan produk. Selanjutnya lembar validasi untuk ahli media meliputi kriteria umum, kriteria khusus, aspek praktis, dan aspek teknis. (b) Angket. Angket adalah daftar pertanyaan yang diberikan kepada orang lain yang bersedia memberikan respons sesuai dengan permintaan pengguna.[17] Tujuan penyebaran angket ialah mencari informasi yang lengkap mengenai suatu masalah dari responden tanpa merasa khawatir dengan jawaban yang 
tidak sesuai dengan kenyataan dalam pengisian daftar pertanyaan. Penilaian terhadap angket menggunakan skala Likert, seperti tertera pada Tabel 2 berikut:

Tabel 2. Skala Likert [17]

\begin{tabular}{lc}
\hline Penilaian & Nilai Skala \\
\hline Sangat Setuju (SS) & 5 \\
\hline Setuju (S) & 4 \\
\hline Netral (N) & 3 \\
\hline Tidak Setuju (TS) & 2 \\
\hline Sangat Tidak Setuju (STS) & 1 \\
\hline
\end{tabular}

(c) Tes hasil belajar. Instrumen ini digunakan untuk mendapatkan data hasil belajar siswa setelah menggunakan e-modul dalam proses pembelajaran. Tes digunakan untuk mengukur efektifitas bahan ajar yang dikembangkan ditinjau dari hasil belajar siswa. Untuk menghasilkan soal yang valid, peneliti melakukan prosedur yang tertera pada Tabel 3 berikut:

Tabel 3. Prosedur-Prosedur Pembuatan Soal Tes

\begin{tabular}{ll}
\hline 1 & Menyusun kisi-kisi soal tes pada materi transformasi geometri \\
\hline 2 & Menyusun butir-butir soal tes berdasarkan kisi-kisi yang telah dibuat \\
\hline 3 & Membuat kunci jawaban soal tes uji coba \\
\hline 4 & Sebelum soal diujikan terlebih dahulu dilakukan validasi terhadap soal tersebut \\
\hline 5 & Melakukan uji coba tes \\
\hline 6 & Analisis butiran soal tes \\
\hline
\end{tabular}

\subsection{Teknik Analisis Data}

Analisis data pada penelitian ini terdiri dari tiga yaitu analisis data validitas, analisis praktikalitas, dan uji efektifitas. Ketiga hal tersebut dijelaskan berikut ini.

\section{Analisis Validitas}

Analisis validitas dilakukan oleh setiap validator dengan memberikan penilaian pada lembar validasi. Hasil validasi kemudian dianalisis menggunakan rumus :

$$
\mathrm{P}=\frac{\text { jumlah skor }}{\text { jumlah skor max }} \times 100 \%
$$

Nilai yang diperoleh selanjutnya diinterpretasi berdasarkan kriteria. Kriteria dinyatakan layak/valid apabila mencapai 81\%-100\% dengan interpretasi data yang tercantum pada Tabel 4 .

Tabel 4. Kriteria Validitas [17]

\begin{tabular}{cc}
\hline Interval & Kategori \\
\hline$<20 \%$ & Tidak Valid \\
\hline $21 \%-40 \%$ & Kurang Valid \\
\hline $41 \%-60 \%$ & Cukup Valid \\
\hline $61 \%-80 \%$ & Valid \\
\hline $81 \%-100 \%$ & Sangat Valid \\
\hline
\end{tabular}

\section{Analisis Praktikalitas}

Menurut KBBI, praktikalitas berarti bahwa bersifat praktis, yaitu mudah dan senang memakainya. Kepraktisan mengacu pada tingkat bahwa pengguna mempertimbangkan intervensi dapat digunakan dan disukai dalam kondisi normal. Untuk mengukur tingkat kepraktisan dapat dilihat dari apakah bahan ajar e-modul yang telah selesai dikembangkan mudah dan dapat digunakan oleh guru dan siswa. Hasil praktikalitas dianalisis dengan menggunakan rumus $\mathrm{P}$ yang terdapat pada analisis validitas. 
Langkah selanjutnya adalah menganalisis data dari hasil angket kemudian diubah menjadi data deskriptif kualitatif dengan kriteria yang terdapat pada Tabel 5 .

Tabel 5. Kriteria Praktikalitas[17]

\begin{tabular}{cc}
\hline Interval & Kategori \\
\hline$<20 \%$ & Tidak Praktis \\
\hline $21 \%-40 \%$ & Kurang Praktis \\
\hline $41 \%-60 \%$ & Cukup Praktis \\
\hline $61 \%-80 \%$ & Praktis \\
\hline $81 \%-100 \%$ & Sangat Praktis \\
\hline
\end{tabular}

\section{Uji Efektifitas}

Efektifitas perangkat pembelajaran dapat dilihat dari hasil belajar yang diberikan kepada siswa setelah menggunakan bahan ajar e-modul. Menurut Sukmadinata [18] hasil belajar merupakan kompetensi pembelajaran siswa dinilai sudah menguasai suatu topik atau kemampuan apabila telah menguasai $75 \%$ atau $80 \%$ dari semua tujuan yang harus dikuasai. Data hasil uji efektifitas dianalisis dengan menggunakan rumus $\mathrm{P}$ yang terdapat pada analisis validitas. Langkah selanjutnya hasil yang diperoleh diinterprestasi dengan kriteria sesuai Tabel 6.

Tabel 6. Kriteria Efektifitas[17]

\begin{tabular}{cc}
\hline Interval & Kategori \\
\hline$<20 \%$ & Tidak Efektif \\
\hline $21 \%-40 \%$ & Kurang Efektif \\
\hline $41 \%-60 \%$ & Cukup Efektif \\
\hline $61 \%-80 \%$ & Efektif \\
\hline $81 \%-100 \%$ & Sangat Efektif \\
\hline
\end{tabular}

\section{Hasil dan Pembahasan}

Pada penelitian ini, yang dikembangkan adalah bahan ajar e-modul dengan materi transformasi geometri. Tahapan pada model 3-D melalui tahapan yaitu define, design, dan develop. Pada tahapan define, merupakan hasil analisis dari sumber belajar yang digunakan oleh guru, literatur tentang bahan ajar e-modul, karakteristik siswa, serta kurikulum matematika pada SMAN 1 Ampek Angkek. Pada tahapan design merupakan proses perancangan bahan ajar e-modul menggunakan aplikasi sigil. Peneliti mengumpulkan semua referensi yang mendukung pembuatan bahan ajar e-modul. Berikut ini susunan kerangka dan format bahan ajar e-modul: (a) Tampilan pertama berisikan cover dan identitas e-modul. (b) Glosarium. (c) Pendahuluan yang berisikan KI, KD, Indikator pembelajaran, dan petunjuk penggunaan bahan ajar e-modul. (d) Kegiatan pembelajaran yang berisikan tujuan pembelajaran, materi, dan kesimpulan. (e) Latihan pembelajaran berisi soal-soal latihan dan kunci jawaban. (f) Daftar pustaka. (g) Biodata penulis.

Tahapan develop melalui langkah-langkah berikut ini. (a) Concept (pengkonsepan) dimana perancangan bahan ajar e-modul ini dapat dijalankan menggunakan media komputer dan android, tanpa menggunakan paket data setelah di download atau dibagikan. Penyajian bahan ajar menggunakan gambar-gambar, video yang dapat membantu siswa memahami pembelajaran dengan cepat. Selain aplikasi utama berupa aplikasi sigil, juga dibantu oleh aplikasi lain berupa microsoft word dengan tipe penyimpanan web page, filtered untuk pembuatan materi dan youcut serta videotrim digunakan untuk memotong durasi video. (b) Design (perancangan). Pada tahapan ini terdiri dari 3 langkah di antaranya pertama, desain 
struktur navigasi yaitu struktur menu pada bahan ajar e-modul menggunakan desain hirarkis, karena menu yang ada saling berhubungan sehingga memungkinkan user untuk berinteraksi dan banyak navigasi dengan menggunakan mouse dalam mengeksplorasi objek pada layar. Yang kedua, desain storyboard. Gambar dari scene, visual desain, audio, durasi, keterangan dan narasi untuk suara akan dibuat pada desain storyboard. Hasil dari storyboard akan menjadi acuan dalam pembuatan tampilan. Ketiga, desain interface. Pada tahapan ini bahan ajar e-modul didesain semenarik mungkin agar siswa lebih tertarik menggunakan sebagai sumber belajar. Selain itu disempurnakan dengan gambar dan video. (d) Material Collecting (pengumpulan bahan) adalah tahapan mengumpulkan gambar, video, background, dan paling utama materi yang akan disampaikan. Pada tahapan ini dilakukan secara paralel dengan tahapan Assembly. (e) Assembly (pembuatan) adalah tahapan pembuatan seluruh objek media pembelajaran berdasarkan desain yang telah dilakukan sebelumnya. Hasil pembuatan desain interface bahan jar e-modul dapat dilihat pada Tabel 7.

Tabel 7. Hasil Pembuatan Bahan Ajar E-Modul Materi Transformasi Geometri

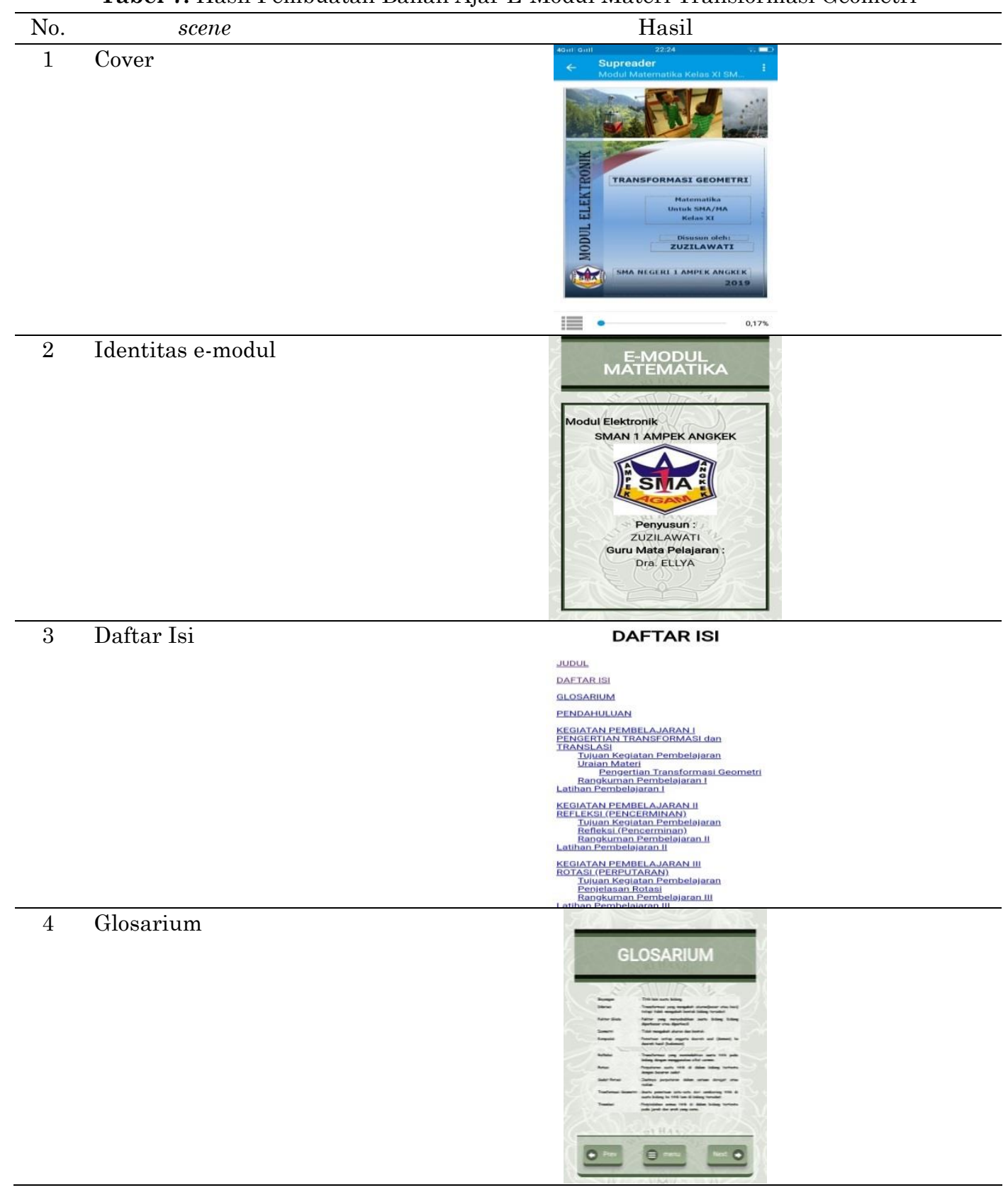




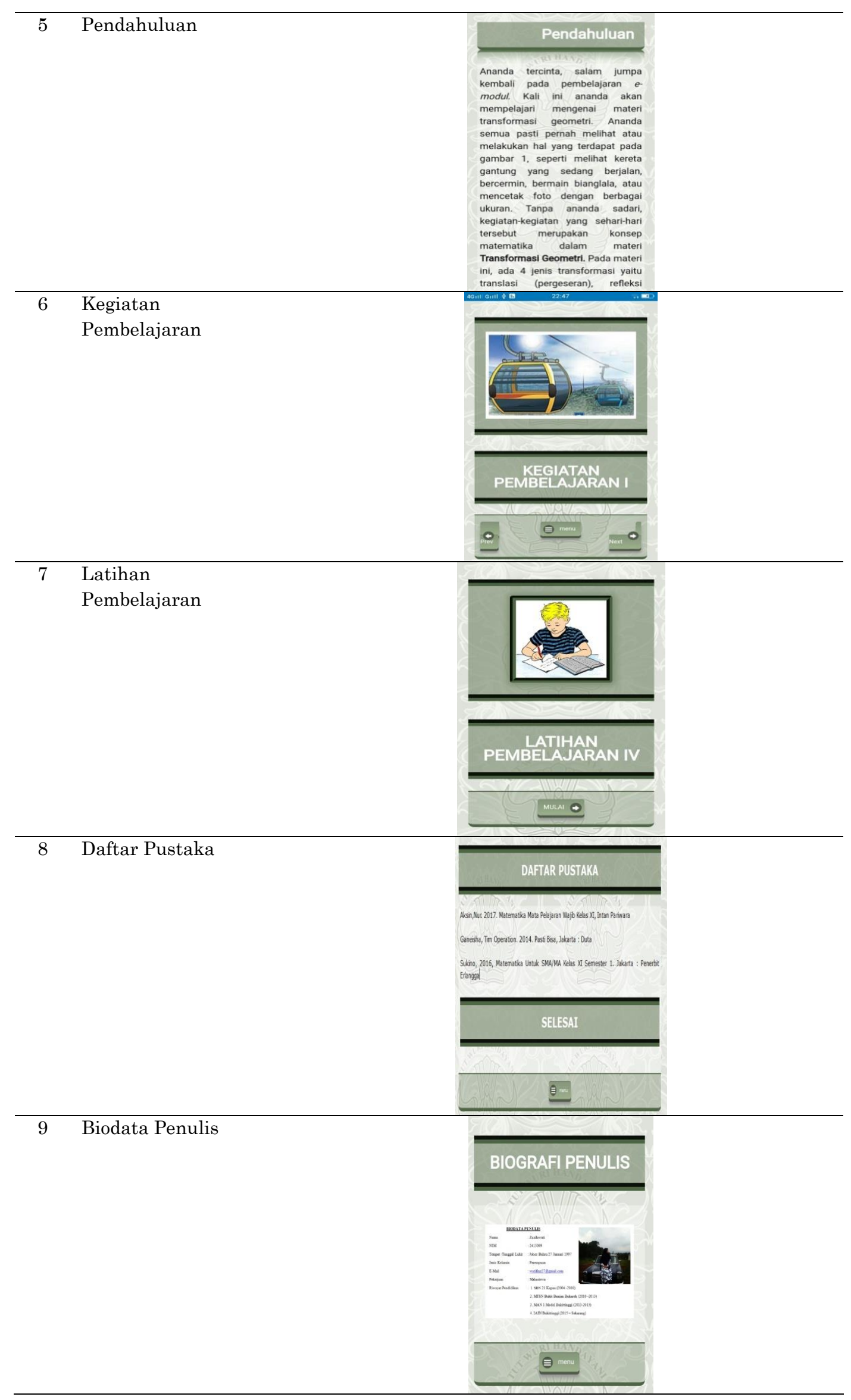


(f) Testing (pengujian) dimana dilakukan uji coba terbatas. Langkah-langkah yang dilakukan adalah berikut ini.

\section{Hasil Validasi Bahan Ajar E-Modul Menggunakan Aplikasi Sigil}

Bahan ajar e-modul di validasi oleh 4 ahli pendidikan matematika dengan hasil dapat dilihat pada Tabel 8 .

Tabel 8. Hasil Rekapitulasi Validasi Bahan Ajar E-Modul pada Ahli Materi dan Pembelajaran

\begin{tabular}{ccc}
\hline No. & Aspek & $\%$ \\
\hline 1 & Tujuan & $80 \%$ \\
\hline 2 & Rasional & $70 \%$ \\
\hline 3 & Isi Modul & $75 \%$ \\
\hline 4 & Karakteristik & $80 \%$ \\
\hline 5 & Kesesuaian dan bahasa & $76 \%$ \\
\hline 6 & Kemasan Prodk & $66,67 \%$ \\
\hline & Rata-rata & $\mathbf{7 4 , 6 1 \%}$ \\
\hline & Kriteria & Valid
\end{tabular}

Sedangkan analisis validasi yang dilakukan oleh 2 ahli media dapat dilihat dari Tabel 9.

Tabel 9. Hasil Rekapitulasi Validasi Bahan Ajar E-Modul pada Ahli Media

\begin{tabular}{ccc}
\hline No. & Kriteria & \% \\
\hline 1 & Umum & $86,67 \%$ \\
\hline 2 & khusus & $86,67 \%$ \\
\hline 3 & Praktis & $85 \%$ \\
\hline 4 & Teknis & $100 \%$ \\
\hline & Rata-rata & $\mathbf{8 9 , 5 9 \%}$ \\
\hline & Kriteria & Sangat Valid \\
\hline
\end{tabular}

Pada Tabel 8 dan Tabel 9 terlihat bahwa hasil dari validator ahli materi dan pendidikan dengan kategori Valid sedangkan validator ahli media dengan kriteria Sangat Valid. Dari kedua hasil tersebut dapat diambil hasil rata-rata dengan memperoleh persentase $82,1 \%$ dengan kategori valid. Hal ini sesuai dengan pendapat Riduwan (2015:13), bahwa rata-rata semua aspek untuk validasi bahan ajar e-modul dengan interval $81 \%-100 \%$ termasuk kategori valid.

\section{Hasil Praktikalitas Bahan Ajar E-Modul Menggunakan Aplikasi Sigil Oleh Guru dan Siswa}

Setelah bahan ajar e-modul selesai divalidasi oleh validator maka dilakukan uji lapangan terbatas. Pengujian produk dilakukan pada pertemuan terakhir setelah guru dan siswa menggunakan bahan ajar e-modul yang bertujuan untuk mengetahui kepraktisan dari bahan ajar e-modul tersebut dengan pemberian angket. Angket praktikalitas diberikan kepada 1 guru matematika yang mengajar kelas uji coba dengan hasil dapat dilihat pada Tabel 10.

Tabel 10. Hasil Rekapitulasi Kepraktisan Bahan Ajar E-Modul oleh Guru

\begin{tabular}{ccc}
\hline No. & Aspek Praktikalitas & $\%$ \\
\hline 1 & Manfaat & $85 \%$ \\
\hline 2 & Kemudahan & $73,33 \%$ \\
\hline 3 & Daya Tarik & $86,67 \%$ \\
\hline & Rata-rata & $\mathbf{8 1 , 6 7 \%}$ \\
\hline & Kriteria & Sangat Praktis
\end{tabular}


Selanjutnya angket praktikalitas diberikan kepada 32 orang siswa dengan hasil dapat dilihat pada Tabel 11.

Tabel 11. Hasil Rekapitulasi Praktikalitas Bahan Ajar E-Modul oleh Siswa

\begin{tabular}{ccc}
\hline No. & Aspek & $\%$ \\
\hline 1 & Kemudahan & $69,38 \%$ \\
\hline 2 & Materi & $80 \%$ \\
\hline 3 & Keterbacaan atau bahasa & $78,44 \%$ \\
\hline 4 & Keberminatan atau kesukaan & $72 \%$ \\
\hline & Rata-rata & $\mathbf{7 5 \%}$ \\
\hline & Kriteria & Praktis
\end{tabular}

Pada Tabel 10 dan Tabel 11 terlihat bahwa hasil kepraktikalitas oleh guru dengan kategori sangat praktis sedangkan hasil kepraktikalitas oleh siswa dengan kriteria praktis. Dari kedua hasil tersebut dapat diambil hasil rata-rata dengan memperoleh persentase $78,34 \%$ dengan kategori Praktis. Hal ini sesuai dengan pendapat Riduwan (2015:13), bahwa rata-rata semua aspek untuk kepraktisan bahan ajar e-modul dengan interval $60 \%-80 \%$ termasuk kategori Praktis.

\section{Hasil Efektifitas Bahan Ajar E-Modul Menggunakan Aplikasi Sigil}

Untuk menentukan keefektifan peneliti memberikan angket uji efektifitas dan menganalisis kemampuan siswa dalam menjawab soal uraian yang diberikan pada pertemuan akhir pembelajaran. Hasil angket uji efektifitas dapat dilihat pada Tabel 12.

Tabel 12. Hasil Rekapitulasi Efektifitas Bahan Ajar E-Modul Menggunakan Apikasi Sigil

\begin{tabular}{ccc}
\hline No. & Aspek & $\%$ \\
\hline 1 & Tampilan & $75,38 \%$ \\
\hline 2 & Isi & $83,33 \%$ \\
\hline 3 & Manfaat & $72,29 \%$ \\
\hline & Rata-rata & $\mathbf{7 7 \%}$ \\
\hline & Kriteria & Efektif
\end{tabular}

Dari Tabel 12 terlihat bahwa hasil keefektifan dengan kategori efektif. Hal ini sesuai dengan pendapat[17], bahwa rata-rata semua aspek untuk keefektifan bahan ajar e-modul dengan interval $60 \%$ - 80 \% termasuk kategori Efektif. Selanjutnya berdasarkan hasil kemampuan siswa untuk menjawab soal uraian diperoleh hasil rata-rata 82,56\%. Dari hasil tersebut dapat disimpulkan bahwa siswa telah mengalami ketuntasan secara klasikal di atas $80 \%$ yang menyatakan bahwa perangkat yang digunakan sangat efektif dalam meningkatkan hasil belajar siswa.

\section{Kesimpulan}

Bahan ajar e-modul menggunakan aplikasi sigil pada materi transformasi geometri yang dikembangkan pada penelitian ini sudah layak digunakan. Hal ini terlihat dari hasil kevalidan sudah menyatakan dengan kriteria sangat valid, hasil kepraktisan sudah menyatakan dengan kriteria praktis, dan hasil keefektifan sudah menyatakan sangat efektif sehingga dapat disimpulkan bahwa produk dapat digunakan sebagai bahan ajar pembelajaran matematika pada kelas XI SMAN 1 Ampek Angkek. Diharapkan kepada penelitian selanjutnya bahan ajar e-modul dapat dikembangkan dengan menggunakan aplikasi yang lain selain sigil sehingga pembelajaran yang dibuat lebih sempurna dan menarik lagi. 


\section{Daftar Pustaka}

[1] Rusman and Etc, Pembelajaran Berbasis Teknologi Informasi dan Komunikasi :

Mengembangkan Profesionalitas Guru. Jakarta: Jakarta: Rajawali Pers, 2011.

[2] B. Warsita, Teknologi Pembelajaran: Landasan dan Aplikasinya. Jakarta: Rineka Cipta, 2008.

[3] PerMenDiknas, Permendiknas No 41 "Standar Proses.” Indonesia, 2007.

[4] A. Mudlofir, Aplikasi Pengembangan Kurikulum Tingkat Satuan Pendidikan dan Bahan Ajar dalam Pendidikan Islam. Jakarta: Rajawali Pers, 2012.

[5] A. Prastowo, Panduan Kreatif Membuat Bahan Ajar Inovatif. Yogyakarta: Diva Press, 2012.

[6] I. K. Y. A. P. Wirawan, I. K. Sudarma, and L. P. P. Mahadewi, "PENGEMBANGAN EMODUL BERBASIS PROBLEM BASED LEARNING UNTUK MATA PELAJARAN IPA SISWA KELAS VII SEMESTER GANJIL SMP NEGERI 1 MELAYA TAHUN PELAJARAN 2017/2018," Edutech, vol. 8, no. 2, pp. 1-8, 2017.

[7] K. A. Priyanthi, A. Ketut, and G. S. Santyadiputra, "Pengembangan E-Modul Berbantuan Simulasi Berorientasi Pemecahan Masalah pada Mata Pelajaran Komunikasi Data," Kumpul. Artik. Mhs. Pendidik. Tek. Inform., vol. 6, no. 1, p. 40, 2017.

[8] F. R. Amalia and R. Kustijono, "PENGEMBANGAN e-BOOKiFISIKA MENGGUNAKAN SIGIL UNTUK MELATIHKAN KETERAMPILAN BERPIKIR KRITIS SISWA SMA,” Inov. Pendidik. Fis., vol. 8, no. 01, pp. 465-469, 2019.

[9] I. Saefullah, Langkah Cepat Menerbitkan Buku Digital Secara Mandiri. Indramayu: Kainoe Books, 2016.

[10] I. Sari, "Pemanfaatan E-Module Menggunakan Sigil Pada Mata Pelajaran TIK di SMAN 1 Mapat Tunggul Selatan," IAIN Bukittinggi, 2019.

[11] P. Maharani, F. Alqodri, and R. A. D. Cahya, "Pemanfaatan Software Sigil Sebagai Media Pembelajaran E-Learning Yang Mudah, Murah dan User Friendly dengan Format Epub sebagai Sumber Materi," in Seminar Nasional Teknologi Informasi dan Multimedia, 2015, vol. 6 , no. 8, pp. 25-30.

[12] I. Binanto, Multimedia Digital Dasar Teori + Pengembangannya. Yogyakarta: Andi Offset, 2010.

[13] P. Setyosari, Metode Penelitian Pendidikan dan Pengembangan. Jakarta: Prenada media Group, 2012.

[14] Trianto, Model Pembelajaran Terpadu. Jakarta: Bumi Aksara, 2011.

[15] M. HAVIZ, "Research and Development; Penelitian Di Bidang Kependidikan Yang Inovatif, Produktif Dan Bermakna," Ta'dib, vol. 16, no. 1, 2016, doi: 10.31958/jt.v16i1.235.

[16] Sugiyono, Metode Penelitian Pendidikan Pendekatan Kuantiatif, Kualitatif, dan R\&D. Bandung: alfabeta, 2015.

[17] Riduwan, Skala Pengukuran Variabel Penelitian. Bandung: alfabeta, 2015.

[18] N. . Sukmadinata, Metode Penelitian Pendidikan. Bandung: Remaja Rosdakarya, 2009. 